\title{
Biogeography of Long-Jawed Spiders Reveals Multiple Colonization of the Caribbean
}

\author{
Klemen Čandek ${ }^{1,2,3, *(\mathbb{D})}$, Ingi Agnarsson ${ }^{4,5,6}{ }^{\mathbb{D}}$, Greta J. Binford ${ }^{7} \mathbb{D}$ and Matjaž Kuntner ${ }^{1,2,5,8} \mathbb{( D )}$ \\ 1 Department of Organisms and Ecosystems Research, National Institute of Biology, 1000 Ljubljana, Slovenia; \\ matjaz.kuntner@nib.si \\ 2 Jovan Hadži Institute of Biology, Research Centre of the Slovenian Academy of the Sciences and Arts, \\ 1000 Ljubljana, Slovenia \\ 3 Department of Biology, Biotechnical Faculty, University of Ljubljana, 1000 Ljubljana, Slovenia \\ 4 Department of Biology, University of Vermont, Burlington, VT 05405, USA; iagnarsson@gmail.com \\ 5 Department of Entomology, National Museum of Natural History, Smithsonian Institution, \\ Washington, DC 20560, USA \\ 6 Faculty of Life and Environmental Sciences, University of Iceland, Sturlugata 7, 102 Reykjavik, Iceland \\ 7 Department of Biology, Lewis and Clark College, Portland, OR 97219, USA; binford@lclark.edu \\ 8 Centre for Behavioural Ecology and Evolution, College of Life Sciences, Hubei University, \\ Wuhan 430011, China \\ * Correspondence: Klemen.candek@nib.si or klemen.candek@gmail.com
}

Citation: Čandek, K.; Agnarsson, I.; Binford, G.J.; Kuntner, M.

Biogeography of Long-Jawed Spiders Reveals Multiple Colonization of the Caribbean. Diversity 2021, 13, 622. https://doi.org/10.3390/d13120622

Academic Editors: Michael Wink and Martín J. Ramírez

Received: 4 October 2021

Accepted: 16 November 2021

Published: 26 November 2021

Publisher's Note: MDPI stays neutral with regard to jurisdictional claims in published maps and institutional affiliations.

Copyright: () 2021 by the authors. Licensee MDPI, Basel, Switzerland. This article is an open access article distributed under the terms and conditions of the Creative Commons Attribution (CC BY) license (https:// creativecommons.org/licenses/by/ $4.0 /)$.

\begin{abstract}
Dispersal ability can affect levels of gene flow thereby shaping species distributions and richness patterns. The intermediate dispersal model of biogeography (IDM) predicts that in island systems, species diversity of those lineages with an intermediate dispersal potential is the highest. Here, we tested this prediction on long-jawed spiders (Tetragnatha) of the Caribbean archipelago using phylogenies from a total of 318 individuals delineated into 54 putative species. Our results support a Tetragnatha monophyly (within our sampling) but reject the monophyly of the Caribbean lineages, where we found low endemism yet high diversity. The reconstructed biogeographic history detects a potential early overwater colonization of the Caribbean, refuting an ancient vicariant origin of the Caribbean Tetragnatha as well as the GAARlandia land-bridge scenario. Instead, the results imply multiple colonization events to and from the Caribbean from the mid-Eocene to late-Miocene. Among arachnids, Tetragnatha uniquely comprises both excellently and poorly dispersing species. A direct test of the IDM would require consideration of three categories of dispersers; however, longjawed spiders do not fit one of these three a priori definitions, but rather represent a more complex combination of attributes. A taxon such as Tetragnatha, one that readily undergoes evolutionary changes in dispersal propensity, can be referred to as a 'dynamic disperser'.
\end{abstract}

Keywords: Tetragnatha; dynamic disperser; intermediate dispersal model of biogeography; GAARlandia; Tetragnathidae

\section{Introduction}

Species distributions and species richness can vastly vary among taxonomic units of comparable ranks. Evolutionary biology aims to understand which factors contribute to such variation $[1,2]$. On the one hand, abiotic factors such as habitable area size, climate conditions or the presence of barriers may all contribute $[3,4]$. On the other hand, biological attributes such as species generation time [5], clade age [6] and species dispersal ability [7,8] may be equally important. Organismal dispersal ability, in particular, has the potential to directly affect levels of gene flow among populations and, consequently, affect species' potential to reach new habitats.

A low dispersal potential of a taxon can limit its colonization success and gene flow among populations, while a high dispersal potential enables the colonization of remote areas and maintains higher levels of gene flow. In theory, both of these extreme cases (low 
and high dispersal) constrain the number of speciation events $[9,10]$. The intermediate dispersal model (IDM) $[9,10]$ predicts that in island systems, the species diversity of those lineages with an intermediate dispersal potential is the highest.

Taxa that contain species with poor dispersal abilities are associated with high levels of endemism, which is often associated with biogeographic patterns of multiple single island endemics across archipelagos $[11,12]$ insofar as extinction rates do not overwhelm their diversification. It is the taxa that contain species with excellent dispersal potential that are usually widely, even globally distributed [13-15]. Studying and understanding the biogeography of species and higher taxonomic ranks on local as well as on global scales could illuminate a clade's intrinsic propensities to disperse. Island systems present compelling biogeographic laboratories [16,17]. Islands are discrete units with different degrees of barriers to gene flow for terrestrial organisms leading to different degrees of adaptation and diversification $[18,19]$. Extreme forms of morphological adaptations or even secondary loss of dispersal abilities in island taxa are not unusual [20-22]. While some species undergo rapid local adaptation and diversification on islands, others readily disperse among islands and form wide distributions across archipelagos.

Comprising over 700 islands and being a genuine biodiversity hotspot, the Caribbean archipelago is among the most suitable natural biogeographic laboratories [19,23]. Although the Caribbean region encompasses adjacent parts of the mainland Americas, the Caribbean islands are classified into three distinct units: the Greater Antilles comprise the large and older islands of Cuba, Hispaniola, Jamaica, and Puerto Rico; the Lesser Antilles are geologically younger, volcanic islands to the east; and the Lucayan Archipelago is the group of tiny Atlantic islands north of the Greater Antilles, mostly encompassing the Bahamas. The Caribbean archipelago has likely been isolated from the mainland since its emergence (see [24] for an overview of the Caribbean geology from a biogeographical perspective); however, a hypothetical land-bridge, GAARlandia, might have connected the greater Antilles with South America between 33 and 35 million years ago (MYA) $[25,26]$ but see [27]. If this land-bridge indeed existed, it would have enabled the colonization of the Caribbean for various organisms, regardless of their dispersal potential.

Spiders are good models in biogeographic research due to the breath of their taxonomic, genetic, evolutionary, and biological diversity [15,28-33]. Spiders represent an ancient lineage with nearly 50 thousand species from 129 families [34] and inhabit most terrestrial ecosystems. Interestingly, various taxonomic groups of comparable ranks within spiders exhibit highly variable dispersal abilities, degrees of endemism, species richness and species distributions $[35,36]$

Our study focuses on long-jawed spiders (genus Tetragnatha, family Tetragnathidae), with special emphasis on the Caribbean archipelago. This diverse genus includes 323 described species [34] (and probably numerous undescribed ones) and has been extensively used in biogeographic research, notably in Hawaii and other Pacific archipelagos [37-40]. While some species are single island endemics, others show extremely wide, even cosmopolitan distributions like T. nitens [34]. Tetragnatha is generally considered to have an extraordinary dispersal potential and is able to quickly reach even the most remote, newly formed islands [37]. This assumption, reinforced by a study of Okuma and Kisimoto (1981) [41], found that $96 \%$ of the aerial plankton collected $400 \mathrm{~km}$ off the Chinese shore were Tetragnatha spiders, passively dispersing through ballooning behavior [35,42].

Here, we report on our study of a rich original collection of Tetragnatha from the Caribbean archipelago. With species delimitation methods we estimate 25 putative species in our original dataset. We then reconstruct the evolutionary history of long-jawed spiders of the Caribbean using a mitochondrial COI gene and a nuclear $28 \mathrm{~S}$ gene fragment. We place the Caribbean phylogeny into a global context by adding a single sequence for numerous published Tetragnatha species on GenBank, increasing the number of putative species to 54 using a Bayesian analysis. Moreover, we estimate the number, the timing, and the directionality of all Caribbean colonization events by Tetragnatha, then look for potential agreement with common biogeographic scenarios on the Caribbean such as colonization by 
overwater dispersal or vicariant origins [43]. As does the paper on Micrathena spiders [44], we also test for a biogeographical pattern in Tetragnatha that would support the hypothetical GAARlandia land-bridge scenario. We contrast the biogeography of Tetragnatha with those of other spider lineages in the Caribbean, including a close relative Cyrtognatha, and broadly estimate the dispersal abilities of Tetragnatha in the context of the IDM.

\section{Materials and Methods}

\subsection{Material Acquisition}

We collected the material for our research as a part of a large-scale Caribbean biogeography (CarBio) project. We used standard methods for collecting the spiders [45,46], namely, day- and night-time beating and a visual aerial search. We fixed the collected material in $96 \%$ ethanol at the site of field work and stored it at $-20 /-80{ }^{\circ} \mathrm{C}$. We then used light microscopy to verify the genus and to identify the species, where possible.

\subsection{Molecular Procedures}

We isolated the DNA using a QIAGEN DNeasy Tissue Kit (Qiagen, Inc., Valencia, CA, USA) at the University of Vermont (Vermont, USA), or an Autogenprep965 automated phenol chloroform extraction at the Smithsonian Institution (Washington, DC, USA), or a robotic DNA extraction with a Mag MAX ${ }^{\mathrm{TM}}$ Express magnetic particle processor Type 700 with DNA Multisample kit (Applied Biosystems, Foster City, CA, USA), following modified protocols [47] at the EZ Lab (Ljubljana, Slovenia).

We targeted two genetic markers, a mitochondrial (COI) and a nuclear one (28S rRNA). We used the forward LCO1490 (GGTCAACAAATCATAAAGATATTGG) [48] and the reverse C1-N-2776 (GGATAATCAGAATATCGTCGAGG) [49] primers for COI amplification. A $25 \mu \mathrm{L}$ reaction volume contained the mixture of: $5 \mu \mathrm{L}$ Promega's GoTaq Flexi Buffer, $0.15 \mu \mathrm{L}$ GoTaq Flexi Polymerase, $0.5 \mu \mathrm{L}$ dNTP's (2 mM each, BioTools), $2.3 \mu \mathrm{L} \mathrm{MgCl}_{2}(25 \mathrm{mM}$, Promega), $0.5 \mu \mathrm{L}$ of each primer $(20 \mu \mathrm{M}), 0.15 \mu \mathrm{L}$ BSA $(10 \mathrm{mg} / \mathrm{mL}$; Promega), $2 \mu \mathrm{L}$ DNA template and sterile distilled water for the remaining volume. We set the PCR cycling protocol as follows: initial denaturation $\left(5 \mathrm{~min}\right.$ at $\left.94{ }^{\circ} \mathrm{C}\right), 20$ repeats $(60 \mathrm{~s}$ at $94{ }^{\circ} \mathrm{C}, 90 \mathrm{~s}$ at $44^{\circ} \mathrm{C}$ while increasing $0.5^{\circ}$ per repeat, $1 \mathrm{~min}$ at $\left.72{ }^{\circ} \mathrm{C}\right), 15$ repeats $(90 \mathrm{~s}$ at $94{ }^{\circ} \mathrm{C}, 90 \mathrm{~s}$ at $53.5^{\circ} \mathrm{C}, 60 \mathrm{~s}$ at $\left.72{ }^{\circ} \mathrm{C}\right)$, and a final elongation $\left(7 \mathrm{~min}\right.$ at $\left.72{ }^{\circ} \mathrm{C}\right)$.

We used the forward 28Sa (also known as 28S-D3A; GACCCGTCTTGAAACA CGGA) [50] and the reverse 28S-rD5b (CCACAGCGCCAGTTCTGCTTAC) [51] primers for $28 \mathrm{~S}$ amplification. The $35 \mu \mathrm{L}$ reaction volume contained the mixture of: $7.1 \mu \mathrm{L}$ Promega's GoTaq Flexi Buffer, 0.2 $\mu \mathrm{L}$ GoTaq Flexi Polymerase, $2.9 \mu \mathrm{L}$ dNTP's ( $2 \mathrm{mM}$ each, BioTools), $3.2 \mu \mathrm{L} \mathrm{MgCl}_{2}$ (25 mM, Promega), $0.7 \mu \mathrm{L}$ of each primer $(20 \mu \mathrm{M}), 0.2 \mu \mathrm{L} \mathrm{BSA}(10 \mathrm{mg} / \mathrm{mL}$; Promega), $1 \mu \mathrm{L}$ DNA template and sterile distilled water for the remaining volume. We set the PCR cycling protocol as follows: initial denaturation $\left(7 \mathrm{~min}\right.$ at $\left.94{ }^{\circ} \mathrm{C}\right), 20$ repeats $(45 \mathrm{~s}$ at $96{ }^{\circ} \mathrm{C}, 45 \mathrm{~s}$ at $62{ }^{\circ} \mathrm{C}$ while decreasing $0.5^{\circ}$ per repeat, $1 \mathrm{~min}$ at $\left.72{ }^{\circ} \mathrm{C}\right), 15$ repeats $(45 \mathrm{~s}$ at $96^{\circ} \mathrm{C}, 45 \mathrm{~s}$ at $52{ }^{\circ} \mathrm{C}, 60 \mathrm{~s}$ at $\left.72{ }^{\circ} \mathrm{C}\right)$, and a final elongation $\left(10 \mathrm{~min}\right.$ at $\left.72{ }^{\circ} \mathrm{C}\right)$.

We used Geneious v. 5.6.7 [52] for the de-novo sequence assembly. We used a combination of MEGA [53] and Mesquite [54] for basic sequence analysis, and for the renaming and concatenating matrices of both genetic markers. We then used the online version of MAFFT [55] for sequence alignment.

We obtained original COI sequences for all 254 specimens and 54 original $28 \mathrm{~S}$ sequences (based on the preliminary species delimitation results; described below) of Tetragnatha spiders. We incorporated an additional 45 Tetragnatha COI sequences from GenBank. These were chosen to be of sufficient quality (over $70 \%$ of overlap with our sequences) and to represent either those species not sampled in the Caribbean, or if sampled there, with clearly outlying populations (such as T. pallescens from Canada). For the outgroups, we used nine COI and seven 28S originally generated sequences as well as ten COI and five 28S sequences mined from GenBank, representing species of Arkys, Linyphia, Meta, Metellina, Pachygnatha, Chrysometa, Cyrtognatha and Leucauge (see Supplementary Table S1 for details). Altogether, our broadest dataset comprised 318 COI sequences and $6628 \mathrm{~S}$ sequences. Our 
specimen selection focused on the Caribbean, but our broad taxon sampling ensured a global representation of Tetragnatha. The concatenated matrix for COI and 28S genes was 1199 nucleotides long, with $649 \mathrm{bp}$ for the COI and $550 \mathrm{bp}$ for the 28S. Relevant specimen details and GenBank accession codes are presented in the Supplementary Table S1.

\subsection{Species Delimitation}

To estimate the number of molecular operational taxonomic units (MOTUs), we analyzed all COI sequences in the dataset using the Automatic Barcode Gap Discovery (ABGD) [56], setting Pmin to 0.001 and Pmax to 0.2 with 30 steps between those values. We set the $\mathrm{X}$ (relative gap width) to different values from 1.5 to 3 to check for the consistency of the results.

\subsection{Phylogenetic Analyses}

\subsubsection{Two Gene, Species Level Phylogeny}

Based on the species delimitation analysis, we selected a subset of the data to create a concatenated matrix (COI and 28S) for a Bayesian phylogenetic reconstruction. We used 54 of the Tetragnatha individuals collected for this work that represent 20 MOTUs and added 12 sequences as outgroups (Supplementary Table S1). We used MrBayes v3.2 [57] with two independent runs, each with four MCMC chains, for 30 million generations. We partitioned the dataset per genetic marker, set a sampling frequency of 2000 and set a relative burn-in to $25 \%$. As the nucleotide substitution model, we used the generalized time-reversible model with gamma distribution and invariant sites $(\mathrm{GTR}+\mathrm{G}+\mathrm{I})$, as per AIC and BIC criteria derived in jModelTest2 [58]. The starting tree was random. We examined the statistical parameters and MCMC chains convergence with sump command within MrBayes and with Tracer v1.7.1 [59]. We visualized the trees with FigTree v1.4.3 [60].

\subsubsection{All-Terminal, Single Gene Phylogeny}

Using MrBayes, we reconstructed two Bayesian phylogenies using all originally sampled Tetragnatha $(\mathrm{N}=254)$ and a single COI sequence for 45 other Tetragnatha species. We added 19 specimens as outgroups (Supplementary Table S1). We included multiple Hawaiian Tetragnatha species belonging to the "spiny-leg" clade, to serve as a check, since their monophyly is well established $[22,40]$ and should thus be recovered in our own phylogenetic reconstructions.

The first all-terminal phylogenetic reconstruction used an unconstrained approach while we enforced the Tetragnatha monophyly for the second one. The settings for both analyses were as in the above species level analysis except with the number of MCMC generations increased to 100 million. Additionally, we set the parameter "contype" within the "sumt" command to "allcompat" to obtain a fully resolved tree.

We then tested whether the unconstrained or the constrained model better fit our data by comparing marginal likelihood scores and by Tracer model comparison analysis. We examined the statistical parameters and MCMC chains convergence with a sump command within MrBayes and with Tracer.

\subsubsection{Caribbean Tetragnatha Monophyly Testing}

To test the Caribbean Tetragnatha monophyly, we ran two additional Bayesian analyses. We created a subset of COI sequences, and a single for each MOTU/recognized species. We then ran the unconstrained analysis and compared it to the analysis with an enforced monophyly of the Caribbean endemic Tetragnatha species. To confirm or reject the monophyly of Tetragnatha species present exclusively on the Caribbean islands, we compared the marginal likelihood scores between the models and ran a Tracer model comparison analysis. The general settings of both (constrained and unconstrained) phylogenetic analyses were as above except with the number of MCMC generations set to 50 million. 


\subsubsection{Time-Calibrated Phylogenetic Reconstruction}

We used BEAST v2.5.1 [60] for a time-calibrated phylogeny on a subsample of the total taxon selection (Table S1). For the substitution model selection, we used a bModelTest [61] expansion in BEAST, following model comparison approaches described by BidegarayBatista and Arnedo (2011) [62]. We selected a relaxed log-normal molecular clock and set the priors accordingly: ucld.mean with normal distribution, mean value of 0.0112 and standard deviation 0.001; ucld.stdev with exponential distribution and a mean value of 0.666 . We set the number of MCMC generations to 30 million with a sampling frequency of 1000. We constrained the topology to comply with the all-terminal COI phylogeny and left BEAST to only estimate branch lengths and associated timing. In the absence of relevant fossils, we used biogeographic and secondary calibrations of the chronogram. The first calibration point was the well-supported appearance of the Hawaiian Islands at 5.1 MYA, therefore the diversification of the Hawaiian clade was constrained with a uniform prior with the upper bound at 5.1 MYA and the lower bound at 0 . We used the second calibration point as the time of the appearance of the Lesser Antillean islands, which are presumably not older than 11 million years [63]. Therefore, the diversification of the clade uniting two putatively Lesser Antillean endemic species (SP5 and SP9) was constrained using a uniform prior with the upper bound at 11 MYA and the lower bound at 0 . The final calibration point originated from the estimated ages for Tetragnathidae at 100 (44-160) [64] and 99 (64-133) MYA [65]. Therefore, we set the MRCA prior on the node Tetragnatha + Arkys (the latter outgroup in Arkyidae) [66] with the following settings: exponential distribution, mean value of 31.5 and 44 offset, corresponding to the soft upper bound at 160 MYA and the hard lower bound at 44.8 MYA.

We used Tracer to determine burn-in, to check for the MCMC convergence and for other statistics. We used TreeAnnotator [60] to summarize trees with a $10 \%$ burn-in and node heights set as median heights. We used FigTree for the maximum clade credibility tree visualization.

\subsection{Ancestral Area Estimation and Biogeographic Stochastic Mapping}

For the biogeographic analyses we employed BioGeoBEARS v0.2.1 [67] implemented in $R$ version 3.5.0 [68] using the ultrametric tree from BEAST with outgroups removed. We conducted the analysis with the remaining 54 species/MOTUs and created a geographic data list with two possible areas: the Caribbean $(\mathrm{C})$ and "Other" $(\mathrm{O})$, meaning there were four possible ancestral states at each node ( $\mathrm{C}, \mathrm{O}, \mathrm{CO}$ and 'null'). Although the Caribbean is a complex island archipelago, we simplified its definition here in order to increase the resolution for estimating biogeographic events between the Caribbean and non-Caribbean areas. We tested all six possible biogeographical models implemented in BioGeoBEARS: DEC $(+\mathrm{J})$, DIVALIKE $(+\mathrm{J})$ and BAYAREALIKE $(+\mathrm{J})$, testing their suitability for our data with Akaike information criterion (AIC) and sample-size corrected AIC (AICc).

To estimate the number and types of biogeographic events in the Caribbean, we performed biogeographical stochastic mapping (BSM) analysis expansion in BioGeoBEARS. We used the most suitable (BAYAREALIKE + J) model, as discovered in the results from previous analysis. We simulated 100 exact biogeographic histories, extracted the estimated number and types of events and presented them as histograms.

\section{Results}

\subsection{Species Delimitation}

We collected 254 individuals from Cuba, Jamaica, Lesser Antilles, Hispaniola, Puerto Rico, South-East USA and Central America (Figure 1, Supplementary Table S1). We confirmed that all individuals were morphologically Tetragnatha and identified eight described species. Using ABGD, we additionally estimated another 17 MOTUs (labeled SP and number; Supplementary Note S1). ABGD was consistent in estimating the number of MOTUs for all tested X (relative gap width) values. Moreover, ABGD detected a 3.8\% 
wide barcoding gap, measured in K2P percent distance [69], closely matching that of the barcoding gap width representative of the family Tetragnathidae [70].

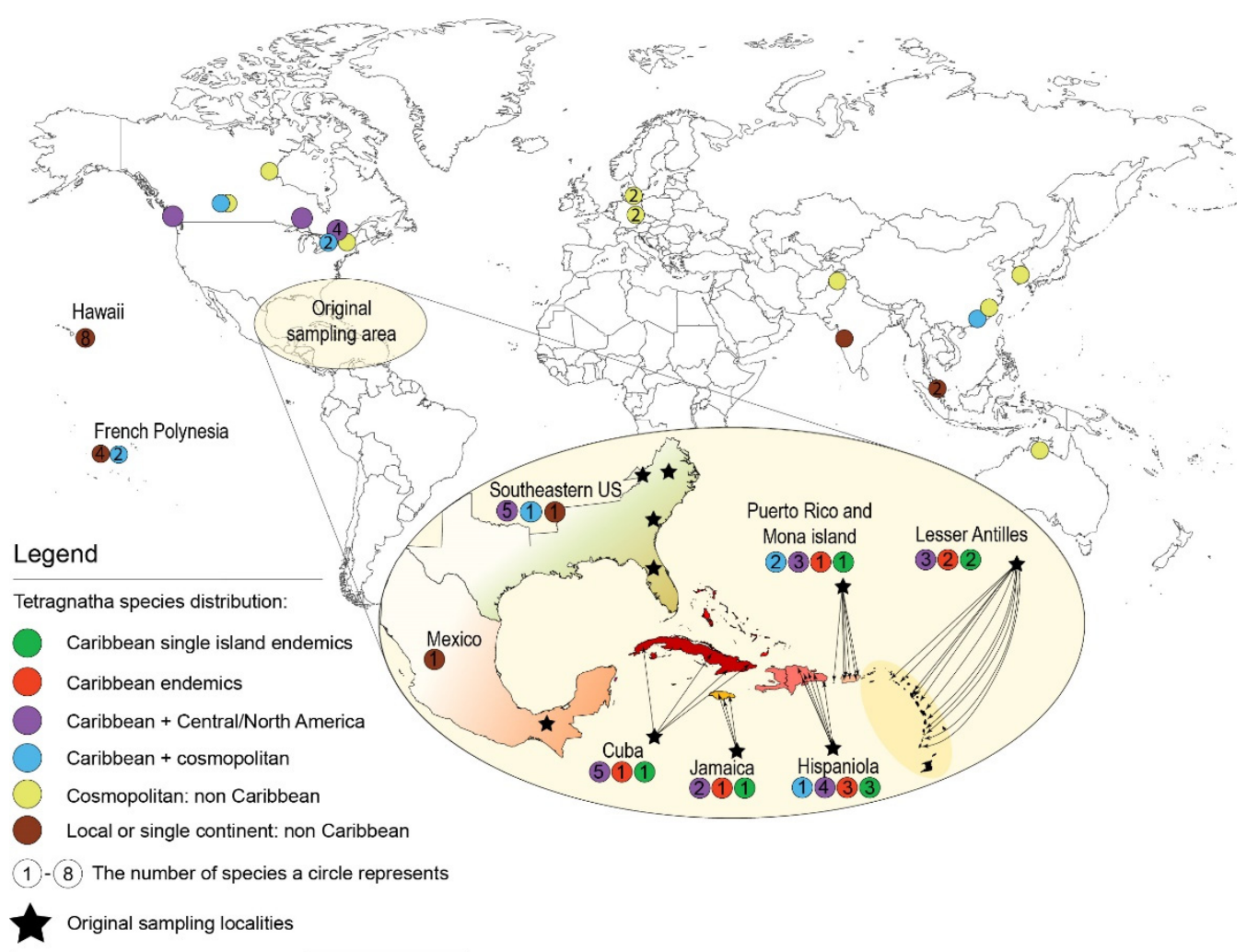

Figure 1. Map of our original sampling localities and origins of GenBank sequences. Circles on the world map and stars in the Caribbean inset indicate where the specimens were collected. Color coding refers to the distribution of a species.

ABGD accurately delimited all species from GenBank with the exception of T. praedonia and T. nigrita. These two species clustered together with a mere $1.1 \%$ sequence divergence between them, suggesting that one of them has been misidentified. Similarly, T. nitens was separated into two species, one of them clustering with T. moua (Supplementary Note S1). This suggests that T. nitens is a species complex, or that it represented another case of GenBank misidentification. Altogether, our originally collected material comprised $25 \mathrm{pu}-$ tative species while together with GenBank sequences our dataset contained 54 putative species. Of those, 11 were Caribbean endemics while 15 species were found both in the Caribbean, as well as elsewhere (Figure 1). In our dataset, 28 species were from outside of the Caribbean.

\subsection{Molecular Phylogeny}

Our two gene, species level phylogeny (Figure 2) supported the Tetragnatha monophyly. A well-supported basal Tetragnatha node contained some, but not all T. shoshone exemplars, refuting the validity of that MOTU. The remaining species/MOTUs generally grouped together with high support. Except for a single node, all internal nodes in this phylogeny were resolved (Figure 2). 


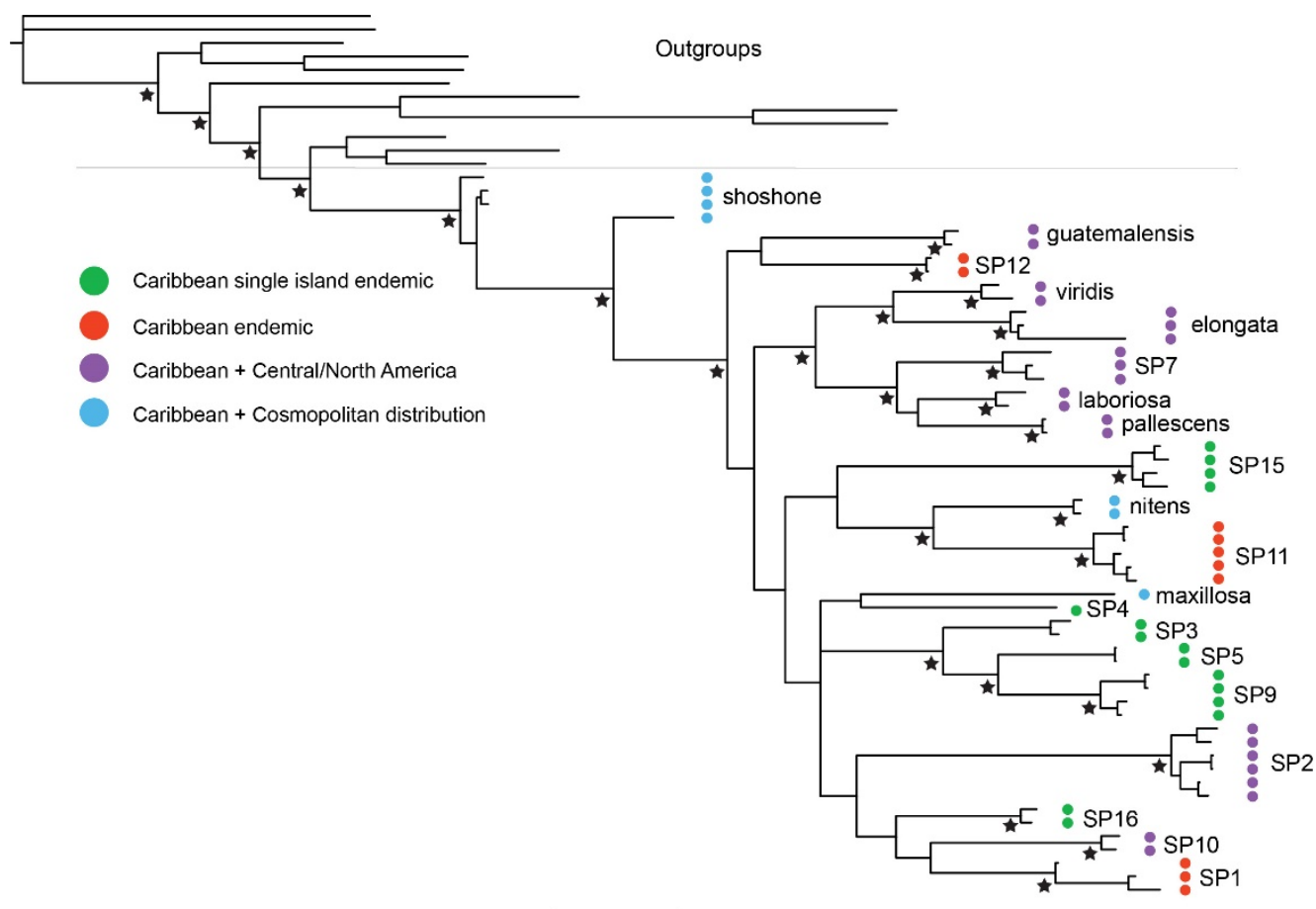

Figure 2. Species level Bayesian phylogeny of the Caribbean Tetragnatha based on COI and 28S. These species relationships support the Tetragnatha monophyly. Stars at nodes indicate Bayesian posterior probability values $>0.95$.

The COI phylogenetic reconstruction in Figure 3 represents the relationships of all originally collected, as well as all data-mined Tetragnatha exemplars. Because the unconstrained all-terminal phylogeny (Figure S1) recovered a paraphyletic Tetragnatha that also included Pachygnatha, we constrained the Tetragnatha monophyly as per the species level results (Figure 3). Occasional inaccuracies at deeper levels of the mitochondrial phylogenies are to be expected due to high saturation levels in COI [71]. Our approach to constrain the allterminal COI phylogeny was justified by the marginal likelihood test with a Tracer model comparison $(\log \mathrm{BF}=710.4 \pm 0.061$ from 500 bootstrap replicates favoring the constrained model). The Hawaiian Tetragnatha always formed a well-supported clade, a result lending credibility to our COI only analyses.

This phylogenetic pattern (Figure 3) reveals eight MOTUs as Caribbean single island endemics and an additional three that are Caribbean endemics. The remaining putative species have more widespread distributions. Although the phylogenetic pattern in itself already hinted at the Caribbean Tetragnatha not being monophyletic, its monophyly was further rejected by the marginal likelihood scores testing with a Tracer model analysis ( $\operatorname{logBF}=163.6 \pm 0.039 \mathrm{SE}$ from 500 bootstrap replicates favoring unconstrained model). The only multispecies Tetragnatha clade recovered as purely Caribbean was the group uniting SP3, 5, 9, and 13. All analyses converged and stabilized with ESS $>300$. 


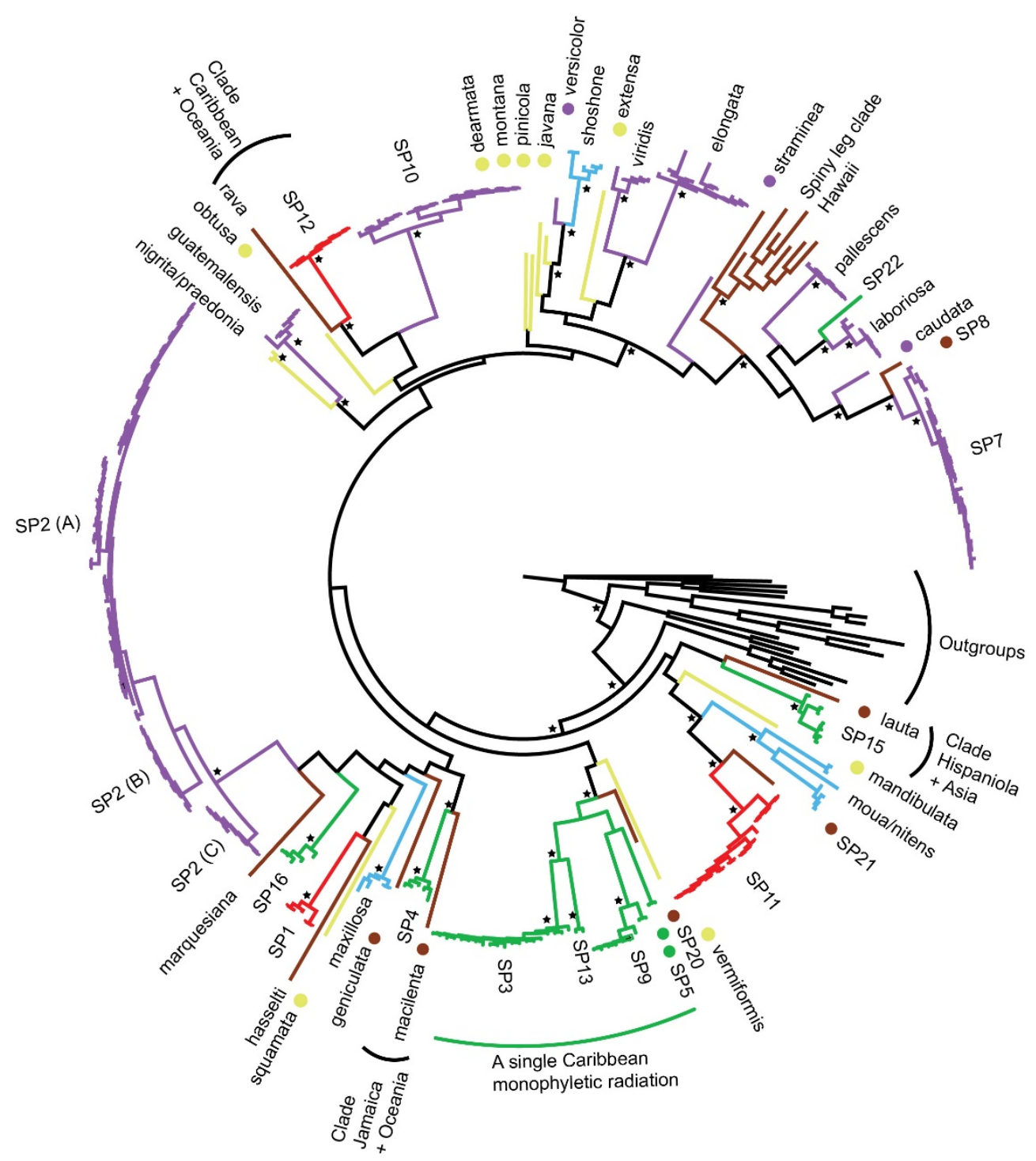

Tetragnatha species distribution:

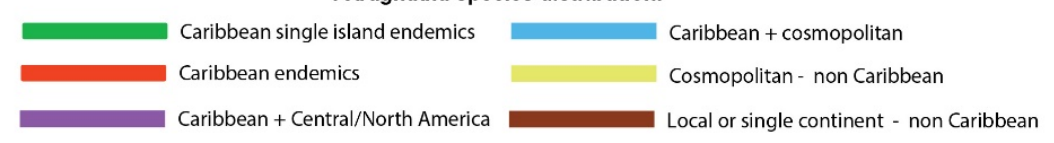

Figure 3. The all-terminal mitochondrial Bayesian phylogeny of the Caribbean and global Tetragnatha representatives. The scattered phylogenetic pattern of single island endemic, Caribbean endemic and cosmopolitan species, as well as highly supported clades of geographically distant relatives reveal a profile of a "dynamic disperser". Note the non-monophyly of the Caribbean Tetragnatha. Stars at nodes indicate Bayesian posterior probability values $>0.90$.

\subsection{Time Calibrated Phylogeny}

The BEAST chronogram suggested that tetragnathids had diverged from their sister family Arkyidae some 58 MYA (million years ago) (95\% HPD 44.5-81.9) (Figure 4). We estimated that the diversification of those Tetragnatha species represented in our dataset had begun some 46 MYA (44-53.3). The Caribbean endemic clade (with species SP3, 5, 9, 13) appears to have diverged from its sister species from Mexico ca. 20 MYA (12.8-29 MYA). Time estimates of the species divergences generally fit the estimated geologic ages of the Caribbean islands. 


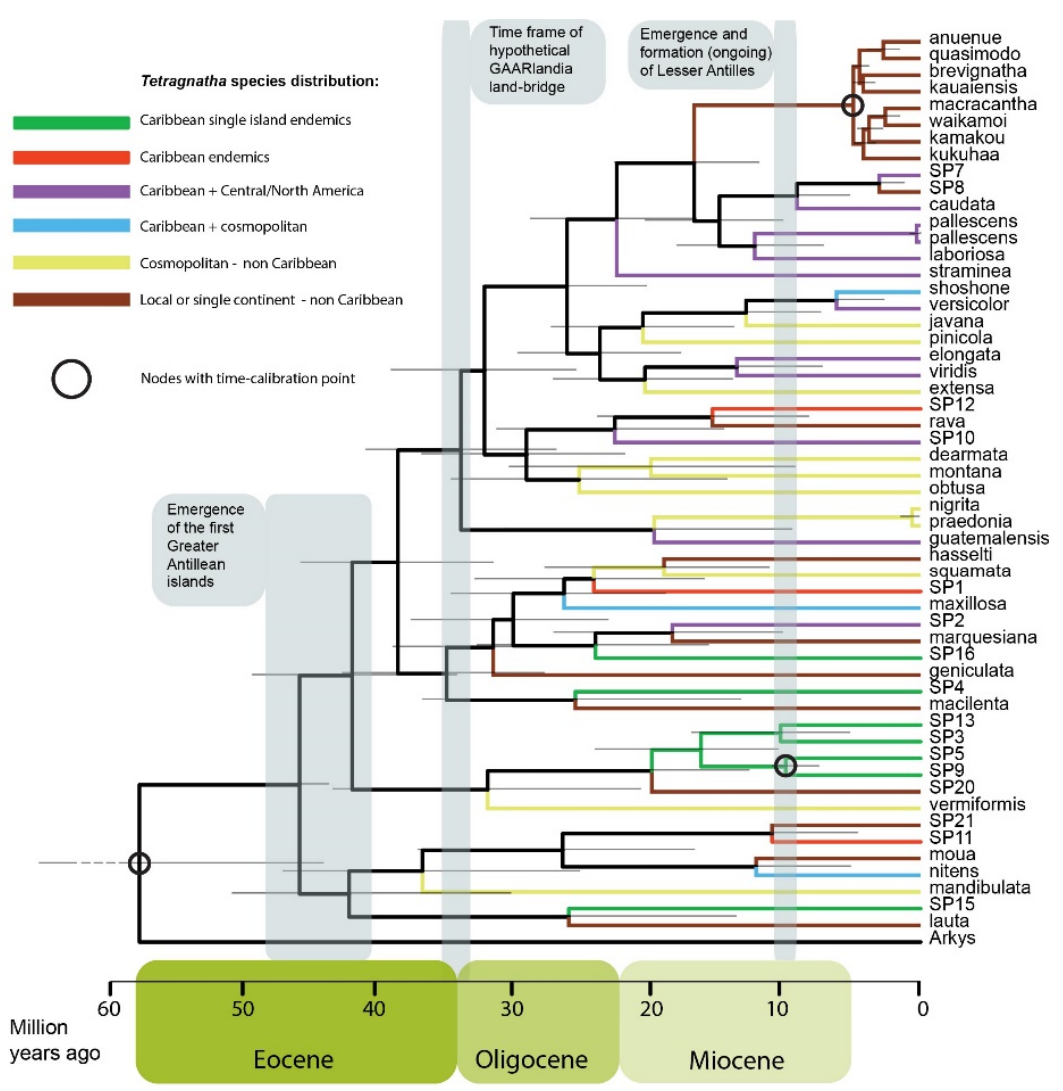

Figure 4. A time-calibrated phylogeny of Tetragnatha. This chronogram from BEAST is consistent with an early Caribbean colonization by Tetragnatha, with multiple overwater dispersal events over the GAARlandia, or with ancient vicariance scenarios. We constrained the topology based on the results from the all-terminal COI phylogeny, therefore, node supports are not shown. Nodal bars represent 95\% HPD intervals.

The examination of log files (all EES > 266) revealed that this BEAST phylogeny was well supported, and additional examination with bModelAnalyzer revealed the most used nucleotide substitution model was a version of TVM, followed by versions of TN93 and GTR (Figure S2) (for details on bModelTest see [61]).

\subsection{Biogeographic Analyses}

BioGeoBEARS model comparison recovered the BAYAREALIKE+J model as the most suitable for our data, regardless of the scoring criterion (Supplementary Table S2). A founder effect within the model ( $+\mathrm{J}$ parameter) showed a significantly better fit for our data than the model without this parameter $(p<0.01)$. The ancestral area estimation (Figure 5) hinted at multiple independent origins of the Caribbean Tetragnatha.

We simulated 100 biogeographic stochastic mapping repeats of exact biogeographic histories (Supplementary Animation S1). This analysis estimated that on average 21.88 biogeographic events took place between the delimited areas. Of those, 11.72 were anagenetic events (all of which were range expansions), and 10.16 were cladogenetic events (Figure 6). Of the latter, all were dispersals with a founder event, and none were vicariant events. The results of narrow sympatry should not be considered in our case because of the experimental design with only two areas. Being extremely wide, the area classified as "Other" would produce a false positive score under narrow sympatry. According to BSM analyses, 17.86 dispersal events must have taken place from outside sources to the Caribbean (9.51 range expansions, 8.35 founder events) while 4.02 dispersal events took place in the opposite direction (2.21 range expansions, 1.81 founder events). 


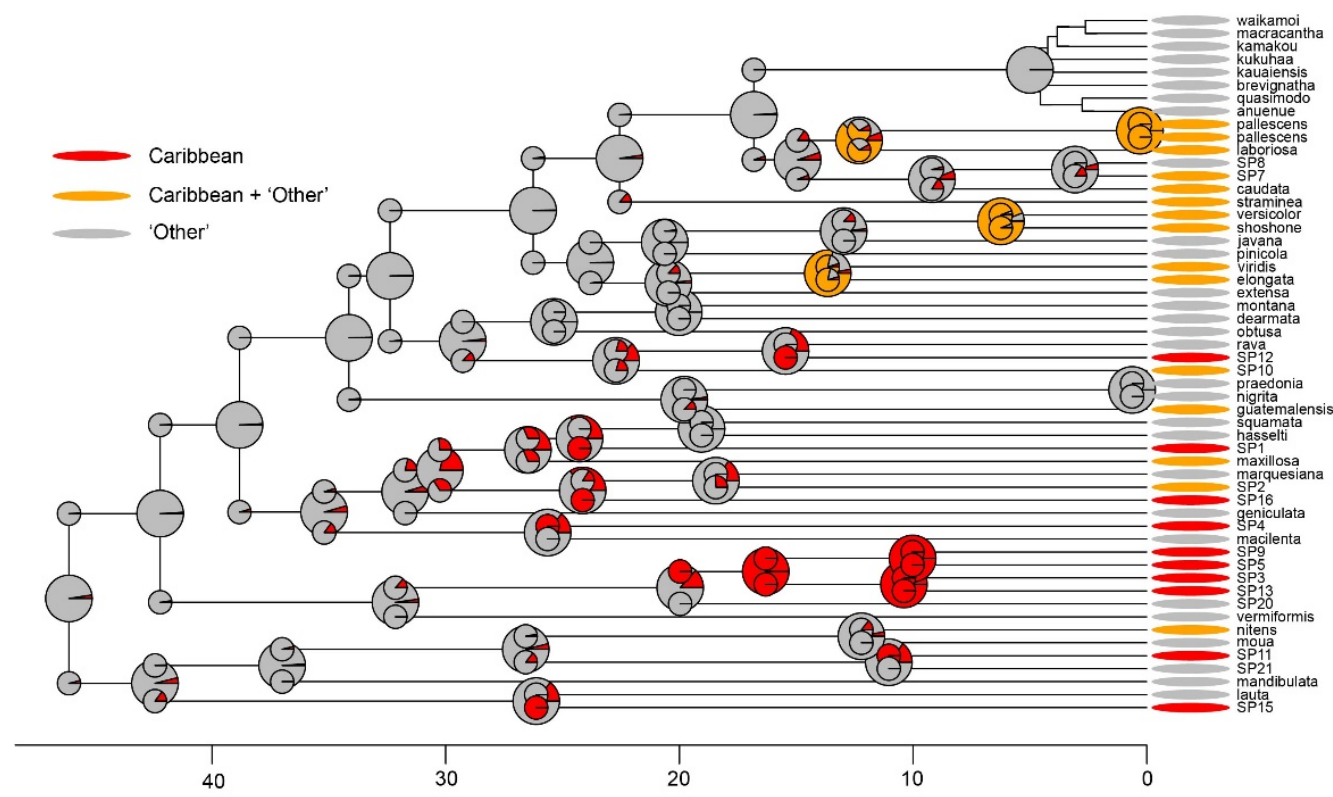

Figure 5. Ancestral area estimation of Tetragnatha. The biogeographical analysis in BioGeoBEARS using the most suitable model for our data (BAYAREALIKE + J, max_range_size $=2$ ), reveals multiple origins of the Caribbean taxa from the outside sources. A single subclade (SP 13, 3, 5, 9) has a well-supported Caribbean ancestral range. Evidently, multiple founder events and range expansion took place throughout Tetragnatha's biogeographic history in the Caribbean.

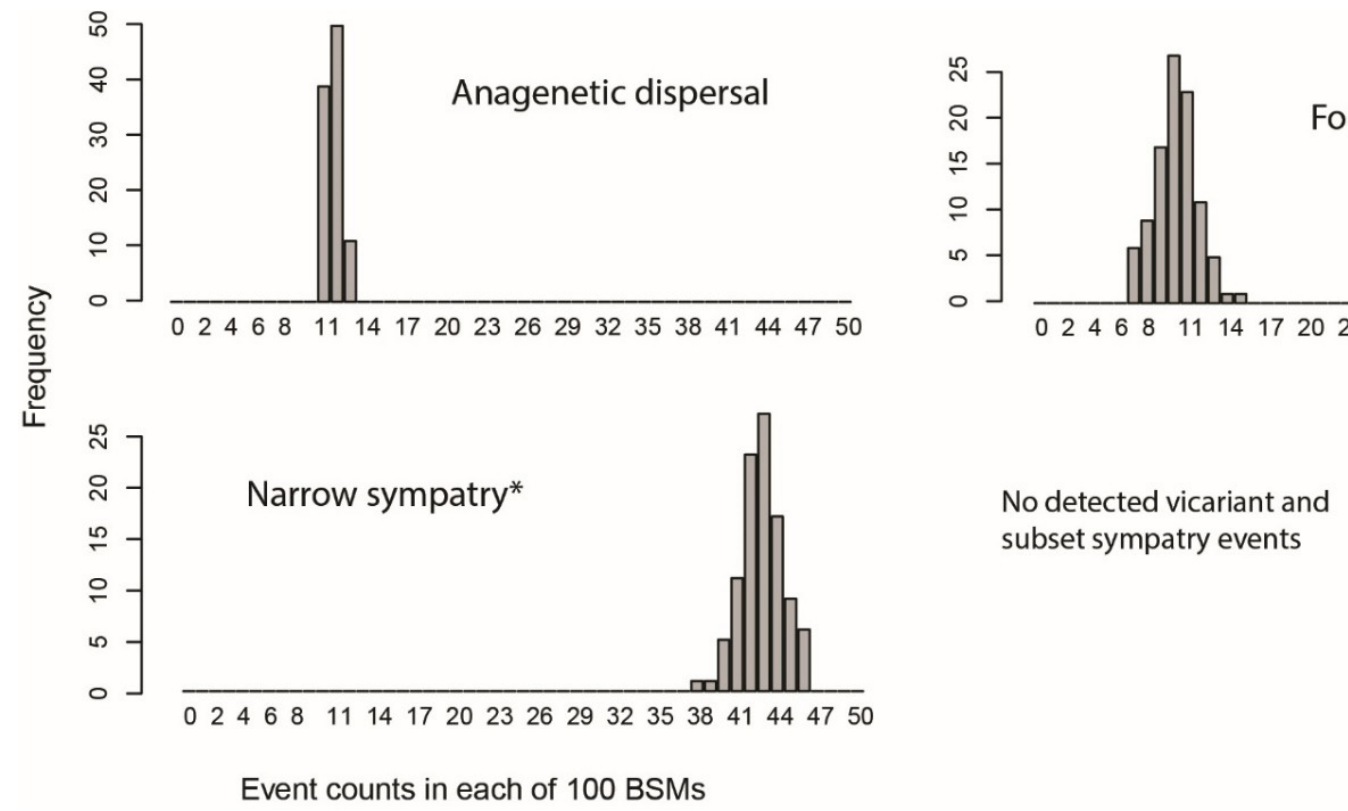

Figure 6. Histogram of event counts from biogeographic stochastic mapping in BioGeoBEARS. Note that * should be interpreted with caution due to experimental design with two areas. The area classified as "Other" is extremely wide and would produce a false positive score under narrow sympatry.

\section{Discussion}

We reconstructed multiple Tetragnatha phylogenies from over 300 individuals of this diverse genus, with a focus on the wider Caribbean region. Our results support the monophyly of the long-jawed spiders but reject the monophyly of the Caribbean Tetragnatha. In the Caribbean, we found low levels of endemism yet a high diversity within Tetragnatha, an unusual pattern considering other spider biogeographic research 
in the Caribbean [24,30-33,72-76]. For example, another orb-weaver, Micrathena, shows a different pattern in the Caribbean, that of a pronounced single island endemism in spite of rampant dispersal history in that clade [44]. The time calibrated phylogenetic reconstruction is consistent with an early overwater colonization of the Caribbean by long-jawed spiders. Moreover, the combination of chronogram and biogeographic history reconstruction refute the possibility of ancient vicariant origins of Caribbean Tetragnatha while favoring overwater dispersals. This result lends no support for the GAARlandia land-bridge hypothesis and lends credibility to the recently reinforced lack of evidence for this land-bridge to have even existed [27]. Biogeographical stochastic mapping recovers multiple colonization events to the Caribbean and evidence of 'reverse colonization' from islands to continents, from the mid-Eocene to late-Miocene. The genus Tetragnatha is exceptionally species rich with well over 300 species worldwide. Of these, our study "only" included 54 species. From the point of view of taxonomic completeness, our biogeographic reconstructions need to be seen as somewhat preliminary; however, the patterns we discuss are likely to be representative of the genus. These results, when compared with other lineages with known biogeographic histories in the Caribbean, suggest a unique dispersal history of Tetragnatha, combining excellent dispersal ability of the lineage as a whole with subsequent reduction or loss of that trait in individual clades through evolutionary history, as also seen in the Hawaiian Tetragnatha [22,77]. As we discuss below, this mixed dispersal biology within the genus Tetragnatha complicates our direct testing of the IDM.

\subsection{Caribbean Tetragnatha Are Not Monophyletic}

Our phylogeny (Figure 2) supports Tetragnatha monophyly; however, combining our results with previously collected data is challenging due to the lack of overlapping $28 \mathrm{~S}$ data available on GenBank. The comparison of this "local" phylogenetic reconstruction, involving exclusively Caribbean species, with the more taxon-rich, global phylogeny, highlights the importance of providing a global context to studies of Caribbean biogeography. While "local" relationships from Figure 2, based upon our sampling, are well supported and appear to tell a clear story, the picture changes substantially with the additional, globally distributed, species. Namely, the all-terminal phylogeny (Figure 3) recovers a complex and mixed pattern in which single island Caribbean endemic species are phylogenetically scattered with other species, some of which are geographically distant. The reasons for such patterns are opaque but could relate to the overall mobility of certain clades that become more global in reach than some others.

Although the phylogeny recovered a single, small-scale, radiation of Caribbean Tetragnatha (the clade with SP3, 5, 9 and 13), overall Caribbean Tetragnatha are not monophyletic. This combined pattern strongly hints at multiple colonization events of Tetragnatha to the archipelago. It further suggests that at least some Tetragnatha species maintain relatively high levels of gene flow within and among the islands, as well as between the archipelago and the continents that serve as source populations. Other species, however, seem to have secondarily lost this dispersal potential and form narrow range endemics. Similarly, research detects the absence of large monophyletic radiations of birds on the Caribbean [19], that are otherwise well documented in bird lineages from more remote archipelagos such as Darwin's finches on the Galapagos [78] and Hawaiian honeycreepers [79]; however, focusing on less mobile organisms, the Caribbean does harbor its own exemplary radiation of Anolis lizards [80-82]. It seems that clade-specific dispersal abilities must coincide with isolation of an island or archipelago to provide the conditions that lead to adaptive radiations [19].

\subsection{Biogeographic History of Caribbean Tetragnatha}

Three hypothetical scenarios of Caribbean biotic colonization are commonly reported. The first scenario, an ancient vicariant hypothesis, assuming the colonization of protoAntilles as early as 70 MYA [83], is refuted by our chronogram (Figure 4). We estimate that Tetragnatha had not appeared on the Caribbean before 46 MYA, with more recent estimates 
even likelier (Figures 4 and 5). Therefore, the ancestral vicariance hypothesis receives no support by our data, because the scenario would predate our time estimates by roughly 30 million years, or more.

The second scenario assumes that non-marine organisms could have used the exposed land-bridge called GAARlandia to reach the Caribbean. GAARlandia may have connected the Greater Antilles with South America between 33 and 35 MYA [25,26], although its very existence is recently questioned [27]. The estimated colonization times of the Caribbean for diverse groups of lineages does seem to coincide with this time period thereby at least indirectly corroborating the possibility of the GAARlandia land-bridge, see fishes [84], frogs [85], mammals [86], invertebrates [32,75,87,88] and plants [89,90], but also see [91]. Our results on Tetragnatha do not support the GAARlandia land-bridge scenario. Specifically, the scattered phylogenetic pattern that suggests repeated colonization of the archipelago by various Tetragnatha species and lineages, refutes a single colonization scenario. A study on Cyrtognatha, another tetragnathid spider genus, also refuted the GAARlandia scenario, but in that case the appearance of the lineage on the archipelago was decisively too recent [24].

The third scenario involves overwater dispersal by terrestrial organisms to reach the Caribbean islands [19]. According to our time estimates (Figure 4) and biogeographic history reconstruction (Figure 5), this scenario best explains our data. Tetragnatha (SP15) could have colonized the Caribbean as early as the mid-Eocene, soon after the emergence of the first Caribbean islands between 40-49 MYA [26,92,93]. Our phylogenetic (Figures 3 and 4) and biogeographic (Figure 5) history reconstructions suggest that Tetragnatha repeatedly, and independently, colonized the Caribbean until mid-Miocene. Moreover, the Tetragnatha biogeographic pattern within the context of the geological history of the Caribbean islands does not support a so-called 'progression rule', a pattern where successive colonization of younger islands is correlated with cladogenesis, e.g., Tetragnatha on Hawaii [94].

Our biogeographical stochastic mapping (BSM) analysis (Supplementary Animation S1, Figure 6) provides strong evidence for multiple colonization events of the Caribbean. Simulating biogeographic histories with BSM is a suitable approach to estimating the average number and directionality of biogeographic events in a studied area $[95,96]$. Within the scope of our analysis, we estimated that, on average, over eight founder events may have taken place in the Caribbean Tetragnatha. The estimation of anagenetic events of range expansion further suggest that Tetragnatha species have expanded their ranges to the Caribbean without subsequent speciation at least nine times. Caribbean Tetragnatha also show evidence of reverse-colonization from islands to the mainland, likely with two range expansions and up to two founder events (Supplementary Table S3).

The reconstructed biogeographic history of the Caribbean Tetragnatha is distinct from biogeographic patterns of Tetragnatha on other, well studied archipelagos. The Marquesas islands were probably colonized once [97], while the Society islands have been colonized at least twice [97]. On these remote Pacific archipelagos, Tetragnatha underwent monophyletic adaptive radiation although on a much smaller scale than Tetragnatha on the Hawaiian archipelago [22,98]. Tetragnatha is thought to have colonized Hawaii between two and four times and with two possible reverse-colonization events, and the subsequent adaptive radiation(s) have produced at least 38 species [40]. The Indian Ocean Mascarene islands were colonized three times without undergoing an adaptive radiation [40]. Considering the above examples, the Caribbean Tetragnatha biogeographic pattern reveals (a) exceptionally high rates of colonization (and reverse-colonization), (b) relatively low levels of endemism, (c) a generally more complex, phylogenetically scattered, species composition, and (d) a very high species richness compared to Tetragnatha from other archipelagos that is only surpassed by Hawaii. We therefore conclude that the Caribbean archipelago offers a unique evolutionary arena. 


\subsection{Tetragnatha Dispersal Abilities}

The all-terminal phylogeny (Figure 3) represents a global picture of the evolutionary history of Tetragnatha. It unveils repeated cases of sister relationships of Caribbean species and geographically distant taxa. Examples are Tetragnatha SP15 from Hispaniola + Tetragnatha lauta from Asia; $T$. SP4 from Jamaica $+T$. macilenta from Oceania; $T$. SP12 from Hispaniola and Puerto Rico + T. rava from Oceania. Our taxon sampling may have omitted numerous extinct or intermediate species that may in fact group within these small but wide-ranging clades. Nonetheless, these well-supported nodes may hold. Similar to our case, Gillespie [97] found that Tetragnatha from the Pacific archipelagos were phylogenetically quite distant relatives.

The extreme geographic distances (over 10,000 km) between pairs of closely related species in our phylogeny (Figure 3), as well as often wide to cosmopolitan distributions of Tetragnatha species, together imply that Tetragnatha must contain numerous species with extraordinary dispersal abilities. The recurring pattern of single island endemism in Tetragnatha hints at evolutionary changes in this dispersal potential where certain species or clades within Tetragnatha have become secondarily dispersal-limited. The genus Tetragnatha exhibits high dispersal abilities and at the same time a high intrinsic property to quickly adapt and diversify, something that can be labeled as "super-speciator" attributes [99,100].

To construct a more general picture of Tetragnatha dispersal ability in the theoretical context of the IDM $[9,10]$, we compare biogeographic patterns of the Caribbean Tetragnatha with those of other Caribbean lineages of spiders. In all cases, the local (Caribbean) as well as global species richness of Tetragnatha is greater than in other genera with putatively poor dispersers such as: Deinopis [32], Micrathena [44,76], Loxosceles and Sicarius [87], Spintharus [30,75], and Selenops [101]. Moreover, attributes associated with putatively poor dispersers such as high levels of single island endemism and low numbers of colonization events are not reconstructed in the case of the Caribbean Tetragnatha. Perhaps as the most relevant comparison, the species richness of the Caribbean Tetragnatha is much higher than that of another member of Tetragnathidae, Cyrtognatha ( 28 vs. 11-14 species; [24]). Given that these genera are closely related, and co-distributed in parts of the region, the differences in their species richness, as well as their biogeographic patterns may, at least in part, be attributed to differences in their dispersal abilities.

Caribbean Tetragnatha also show strikingly different patterns compared with some of the spider genera with putatively excellent dispersal abilities, such as Trichonephila $[14,33]$ and Argiope [31,102]. Trichonephila is distributed across the whole Caribbean archipelago but is represented by a single extant species, T. clavipes. Although several species of Argiope occupy the Caribbean, the most widespread is $A$. argentata (a recently discovered cryptic species $A$. butchko used to be $A$. argentata in part) [31]. This comparison, in addition to the previous comparison with putatively poor dispersers, reveals a much higher local (Caribbean) and global species richness in Tetragnatha than in Trichonephila or Argiope. Moreover, the a priori expected biogeographic pattern with the combination of rare founder events, low number of widely distributed species, and extremely low endemism, all purportedly associated with excellent dispersal ability, is not reconstructed in the Caribbean Tetragnatha. Tetragnatha is an excellent disperser but appears to readily respond to natural selection upon colonizing islands, which may render individual species to change their dispersal behavior and become endemic. While a direct test of the IDM would require consideration of three, more or less discrete, categories of dispersers (excellent, poor, and intermediate), long-jawed spiders do not readily fit one of these three a priori definitions. Instead, they represent a more complex combination of attributes of a 'dynamic disperser'.

\section{Conclusions}

Our phylogenetic research of the Caribbean Tetragnatha reveals a complex biogeographic history with multiple colonization events to and from the Caribbean. A combination of geographically scattered, closely related species, single island endemics, cosmopoli- 
tan species, multiple dispersal events, as well as the high species richness of the Caribbean Tetragnatha, presents a unique model for comparative biogeographic research.

Considering the theoretical framework of the IDM $[9,10]$, one cannot classify Tetragnatha into one of the three a priori definitions of dispersers (poor vs. intermediate vs. excellent). Instead, they represent a more complex combination of attributes, something we refer to as a 'dynamic disperser'. This refers to a taxon that readily undergoes evolutionary changes in dispersal propensity. In line with the predictions of the IDM, some highly dispersive Tetragnatha species fail to speciate, even on more remote islands; however, some lineages have apparently secondarily lost their dispersal ability, thus forming narrow endemic species or groups. While preliminary evidence points towards the general validity of the IDM, more stringent testing will require a less simplistic a priori binning of the dispersal categories of organisms. Nonetheless, our findings demonstrate the very dynamic relationship between dispersal ability and diversity and how changes in dispersal propensity may link to endemism.

Supplementary Materials: The following are available online at https:/ /www.mdpi.com/article/10 .3390/d13120622/s1, Table S1: specimen details and GenBank codes, Table S2: BioGeoBEARS model comparison results, Table S3: BioGeoBEARS stochastic mapping results, Supplementary Animation S1. Note S1: ABGD analyses results, Figure S1: unconstrained all-terminal COI Tetragnatha phylogeny and Figure S2: detailed results of bModelTest model selection.

Author Contributions: Conceptualization, all authors; methodology, K.Č.; formal analysis, K.Č.; writing—original draft preparation, K.Č. and M.K.; writing—review and editing, all authors; visualization, K.Č.; supervision, M.K.; project administration, M.K., I.A. and G.J.B.; funding acquisition, M.K., I.A. and G.J.B. All authors have read and agreed to the published version of the manuscript.

Funding: This work was supported by grants from the National Science Foundation (DEB-1314749, DEB-1050253), and the Slovenian Research Agency (J1-6729, J1-9163, P1-0255, P1-0236, BI-US/17-18-011).

Institutional Review Board Statement: Not applicable.

Informed Consent Statement: Not applicable.

Data Availability Statement: All results generated in this study and protocols needed to replicate them are included in this published article, public repositories (GenBank) and supplementary material files.

Acknowledgments: We thank the CarBio team (http:/ / www.islandbiogeography.org/participants. html, accessed on 15 November 2021) for collecting the material across the Caribbean. Moreover, we thank Lisa Chamberland and other members of the Agnarsson lab (http:/ / www.theridiidae.com/ lab-members.html, accessed on 15 November 2021) for the help with material sorting and molecular procedures. We thank three anonymous reviewers for their constructive comments that improved this paper.

Conflicts of Interest: The authors declare no conflict of interest.

\section{References}

1. Kozak, K.H.; Wiens, J.J. What explains patterns of species richness? The relative importance of climatic-niche evolution, morphological evolution, and ecological limits in salamanders. Ecol. Evol. 2016, 6, 5940-5949. [CrossRef]

2. Kozak, K.H.; Wiens, J.J. Testing the Relationships between Diversification, Species Richness, and Trait Evolution. Syst. Biol. 2016, 65, 975-988. [CrossRef] [PubMed]

3. Rabosky, D.L.; Hurlbert, A.H. Species richness at continental scales is dominated by ecological limits. Am. Nat. 2015, 185, 572-583. [CrossRef] [PubMed]

4. Schluter, D.; Pennell, M.W. Speciation gradients and the distribution of biodiversity. Nature 2017, 546, 48-55. [CrossRef]

5. Rajakaruna, H.; Lewis, M. Do yearly temperature cycles reduce species richness? Insights from calanoid copepods. Theor. Ecol. 2018, 11, 39-53. [CrossRef]

6. Marin, J.; Hedges, S.B. Time best explains global variation in species richness of amphibians, birds and mammals. J. Biogeogr. 2016, 43, 1069-1079. [CrossRef]

7. Borda-de-Água, L.; Whittaker, R.J.; Cardoso, P.; Rigal, F.; Santos, A.M.C.C.; Amorim, I.R.; Parmakelis, A.; Triantis, K.A.; Pereira, H.M.; Borges, P.A.V. Dispersal ability determines the scaling properties of species abundance distributions: A case study using arthropods from the Azores. Sci. Rep. 2017, 7, 3899. [CrossRef] [PubMed] 
8. Lenoir, J.; Virtanen, R.; Oksanen, J.; Oksanen, L.; Luoto, M.; Grytnes, J.A.; Svenning, J.C. Dispersal ability links to cross-scale species diversity patterns across the Eurasian Arctic tundra. Glob. Ecol. Biogeogr. 2012, 21, 851-860. [CrossRef]

9. Claramunt, S.; Derryberry, E.P.; Remsen, J.V.; Brumfield, R.T. High dispersal ability inhibits speciation in a continental radiation of passerine birds. Proc. R. Soc. B Biol. Sci. 2012, 279, 1567-1574. [CrossRef] [PubMed]

10. Agnarsson, I.; Cheng, R.-C.; Kuntner, M. A multi-clade test supports the intermediate dispersal model of biogeography. PLoS ONE 2014, 9, e86780. [CrossRef]

11. Opatova, V.; Arnedo, M.A. Spiders on a Hot Volcanic Roof: Colonisation Pathways and Phylogeography of the Canary Islands Endemic Trap-Door Spider Titanidiops canariensis (Araneae, Idiopidae). PLoS ONE 2014, 9, e115078. [CrossRef] [PubMed]

12. Pitta, E.; Kassara, C.; Tzanatos, E.; Giokas, S.; Sfenthourakis, S. Between-island compositional dissimilarity of avian communities. Ecol. Res. 2014, 29, 835-841. [CrossRef]

13. Essl, F.; Steinbauer, K.; Dullinger, S.; Mang, T.; Moser, D. Telling a different story: A global assessment of bryophyte invasions. Biol. Invasions 2013, 15, 1933-1946. [CrossRef]

14. Kuntner, M.; Agnarsson, I. Phylogeography of a successful aerial disperser: The golden orb spider Nephila on Indian Ocean islands. BMC Evol. Biol. 2011, 11, 119. [CrossRef]

15. Turk, E.; Čandek, K.; Kralj-Fišer, S.; Kuntner, M. Biogeographical history of golden orbweavers: Chronology of a global conquest. J. Biogeogr. 2020, 47, 1333-1344. [CrossRef]

16. Darwin, C. On the Origin of the Species; John Murray: London, UK, 1859; Volume 5, ISBN 1546622497.

17. Warren, B.H.; Simberloff, D.; Ricklefs, R.E.; Aguilée, R.; Condamine, F.L.; Gravel, D.; Morlon, H.; Mouquet, N.; Rosindell, J.; Casquet, J.; et al. Islands as model systems in ecology and evolution: Prospects fifty years after MacArthur-Wilson. Ecol. Lett. 2015, 18, 200-217. [CrossRef] [PubMed]

18. Reynolds, R.G.; Collar, D.C.; Pasachnik, S.A.; Niemiller, M.L.; Puente-Rolón, A.R.; Revell, L.J. Ecological specialization and morphological diversification in Greater Antillean boas. Evolution 2016, 70, 1882-1895. [CrossRef]

19. Ricklefs, R.E.; Bermingham, E. The West Indies as a laboratory of biogeography and evolution. Philos. Trans. R. Soc. B Biol. Sci. 2008, 363, 2393-2413. [CrossRef]

20. Frankham, R. Inbreeding and Extinction: Island Populations. Conserv. Biol. 2008, 12, 665-675. [CrossRef]

21. Meiri, S. Oceanic island biogeography: Nomothetic science of the anecdotal. Front. Biogeogr. 2017, 9, e32081. [CrossRef]

22. Gillespie, R.G.; Croom, H.B.; Hasty, G.L. Phylogenetic Relationships and Adaptive Shifts among Major Clades of Tetragnatha Spiders (Araneae: Tetragnathidae) in Hawaí. Pacific Sci. 1997, 51, 380-394.

23. Crews, S.C.; Esposito, L.A. Towards a synthesis of the Caribbean biogeography of terrestrial arthropods. BMC Evol. Biol. 2020, 20, 12. [CrossRef]

24. Čandek, K.; Agnarsson, I.; Binford, G.J.; Kuntner, M. Biogeography of the Caribbean Cyrtognatha spiders. Sci. Rep. 2019, 9, 397. [CrossRef]

25. Ali, J.R. Colonizing the Caribbean: Is the GAARlandia land-bridge hypothesis gaining a foothold? J. Biogeogr. 2012, 39, 431-433. [CrossRef]

26. Iturralde-Vinent, M.A.; MacPhee, R.D.E. Paleogeography of the Caribbean Region: Implications for Cenozoic Biogeography. Bull. Am. Museum Nat. Hist. 1999, 238, 791. [CrossRef]

27. Ali, J.R.; Hedges, S.B. Colonizing the Caribbean: New geological data and an updated land-vertebrate colonization record challenge the GAARlandia land-bridge hypothesis. J. Biogeogr. 2021, 48, jbi.14234. [CrossRef]

28. Gillespie, R.G.; Benjamin, S.P.; Brewer, M.S.; Rivera, M.A.J.; Roderick, G.K. Repeated Diversification of Ecomorphs in Hawaiian Stick Spiders. Curr. Biol. 2018, 28, 941-947.e3. [CrossRef]

29. Cotoras, D.D.; Bi, K.; Brewer, M.S.; Lindberg, D.R.; Prost, S.; Gillespie, R.G. Co-occurrence of ecologically similar species of Hawaiian spiders reveals critical early phase of adaptive radiation. BMC Evol. Biol. 2018, 18, 100. [CrossRef] [PubMed]

30. Agnarsson, I.; van Patten, C.; Sargeant, L.; Chomitz, B.; Dziki, A.; Binford, G.J. A radiation of the ornate Caribbean 'smiley-faced spiders', with descriptions of 15 new species (Araneae: Theridiidae, Spintharus). Zool. J. Linn. Soc. 2018, 182, 758-790. [CrossRef]

31. Agnarsson, I.; LeQuier, S.M.; Kuntner, M.; Cheng, R.-C.; Coddington, J.A.; Binford, G.J. Phylogeography of a good Caribbean disperser: Argiope argentata (Araneae, Araneidae) and a new 'cryptic' species from Cuba. Zookeys 2016, 2016, 25-44. [CrossRef] [PubMed]

32. Chamberland, L.; McHugh, A.; Kechejian, S.; Binford, G.J.; Bond, J.E.; Coddington, J.; Dolman, G.; Hamilton, C.A.; Harvey, M.S.; Kuntner, M.; et al. From Gondwana to GAARlandia: Evolutionary history and biogeography of ogre-faced spiders (Deinopis). J. Biogeogr. 2018, 45, 2442-2457. [CrossRef]

33. Čandek, K.; Agnarsson, I.; Binford, G.J.; Kuntner, M. Caribbean golden orbweaving spiders maintain gene flow with North America. Zool. Scr. 2020, 49, 210-221. [CrossRef]

34. World Spider Catalog World Spider Catalog. 2021. Available online: https://wsc.nmbe.ch/ (accessed on 10 October 2021).

35. Foelix, R. Biology of Spiders, 3rd ed.; Oxford University Press: Oxford, UK, 2011; ISBN 9780199734825.

36. Čandek, K.; Pristovšek Čandek, U.; Kuntner, M. Machine learning approaches identify male body size as the most accurate predictor of species richness. BMC Biol. 2020, 18, 105. [CrossRef] [PubMed]

37. Cotoras, D.D.; Murray, G.G.R.; Kapp, J.; Gillespie, R.G.; Griswold, C.E.; Simison, W.B.; Green, R.E.; Shapiro, B. Ancient DNA resolves the history of Tetragnatha (Araneae, Tetragnathidae) spiders on Rapa Nui. Genes 2017, 8, 403. [CrossRef] 
38. Gillespie, R.G. Spiders of the Genus Tetragnatha) (Araneae, Tetragnathidae) in the Society Islands. J. Arachnol. $2003,31,157-172$. [CrossRef]

39. Gillespie, R.G. Geographical context of speciation in a radiation of Hawaiian Tetragnatha spiders (Araneae, Tetragnathidae). J. Arachnol. 2005, 33, 313-322. [CrossRef]

40. Casquet, J.; Bourgeois, Y.X.C.; Cruaud, C.; Gavory, F.; Gillespie, R.G.; Thébaud, C. Community assembly on remote islands: A comparison of Hawaiian and Mascarene spiders. J. Biogeogr. 2015, 42, 39-50. [CrossRef]

41. Okuma, C.; Kisimoto, R. Airborne spiders collected over the East China Sea. Jpn. J. Appl. Entomol. Zool. 1981, 25, 296-308. [CrossRef]

42. Bell, J.R.; Bohan, D.A.; Shaw, E.M.; Weyman, G.S. Ballooning dispersal using silk: World fauna, phylogenies, genetics and models. Bull. Entomol. Res. 2005, 95, 69-114. [CrossRef]

43. Hedges, S.B. Paleogeography of the Antilles and Origin of West Indian Terrestrial Vertebrates. Ann. Missouri Bot. Gard. 2006, 93, 231-244. [CrossRef]

44. Shapiro, L.; Binford, G.J.; Agnarsson, I. Single island endemism despite repeated dispersal in Caribbean Micrathena (Araneae: Araneidae), an updated phylogeographic analysis. Diversity 2021, 13, 1-27, in press.

45. Agnarsson, I.; Coddington, J.A.; Kuntner, M. Systematics: Progress in the study of spider diversity and evolution. In Spider Research in the 21st Century: Trends and Perspectives; Penney, D., Ed.; Siri Scientific Press: Manchester, UK, 2013; pp. 55-111. ISBN 0957453019.

46. Coddington, J.A.; Griswold, C.E.; Silva, D.; Peqaranda, E.; Larcher, S.F.; Penaranda, E.; Larcher, S.F. Designing and testing sampling protocols to estimate biodiversity in tropical ecosystems. In The Unity of Evolutionary Biology: Proceedings of the Fourth International Congress of Systematic and Evolutionary Biology; Dioscorides Press: Portland, OR, USA, 1991; pp. 44-60.

47. Vidergar, N.; Toplak, N.; Kuntner, M. Streamlining DNA barcoding protocols: Automated DNA extraction and a new cox1 primer in arachnid systematics. PLoS ONE 2014, 9, e113030. [CrossRef]

48. Folmer, O.; Black, M.; Hoeh, W.; Lutz, R.; Vrijenhoek, R. DNA primers for amplification of mitochondrial cytochrome c oxidase subunit I from diverse metazoan invertebrates. Mol. Mar. Biol. Biotechnol. 1994, 3, 294-299. [CrossRef]

49. Hedin, M.C.; Maddison, W.P. A Combined Molecular Approach to Phylogeny of the Jumping Spider Subfamily Dendryphantinae (Araneae: Salticidae). Mol. Phylogenet. Evol. 2001, 18, 386-403. [CrossRef] [PubMed]

50. Nunn, G.B.; Theisen, B.F.; Christensen, B.; Arctander, P. Simplicity-correlated size growth of the nuclear $28 \mathrm{~S}$ ribosomal RNA D3 expansion segment in the crustacean order isopoda. J. Mol. Evol. 1996, 42, 211-223. [CrossRef] [PubMed]

51. Whiting, M.F. Mecoptera is paraphyletic: Multiple genes and phylogeny of Mecoptera and Siphonaptera. Zool. Scr. 2002, 31, 93-104. [CrossRef]

52. Kearse, M.; Moir, R.; Wilson, A.; Stones-Havas, S.; Cheung, M.; Sturrock, S.; Buxton, S.; Cooper, A.; Markowitz, S.; Duran, C.; et al. Geneious Basic: An integrated and extendable desktop software platform for the organization and analysis of sequence data. Bioinformatics 2012, 28, 1647-1649. [CrossRef] [PubMed]

53. Tamura, K.; Stecher, G.; Peterson, D.; Filipski, A.; Kumar, S. MEGA6: Molecular Evolutionary Genetics Analysis Version 6.0. Mol. Biol. Evol. 2013, 30, 2725-2729. [CrossRef]

54. Maddison, W.P.; Maddison, D.R. Mesquite: A modular system for evolutionary analysis. Evolution 2008, 62, 1103-1118.

55. Katoh, K.; Standley, D.M. MAFFT Multiple Sequence Alignment Software Version 7: Improvements in Performance and Usability. Mol. Biol. Evol. 2013, 30, 772-780. [CrossRef]

56. Puillandre, N.; Lambert, A.; Brouillet, S.; Achaz, G. ABGD, Automatic Barcode Gap Discovery for primary species delimitation. Mol. Ecol. 2012, 21, 1864-1877. [CrossRef]

57. Huelsenbeck, J.P.; Ronquist, F. MrBayes: Bayesian inference of phylogenetic trees. Bioinformatics 2001, 17, 754-755. [CrossRef]

58. Darriba, D.; Taboada, G.L.; Doallo, R.; Posada, D. jModelTest 2: More models, new heuristics and parallel computing. Nat. Methods 2012, 9, 772. [CrossRef]

59. Rambaut, A.; Drummond, A.J.; Xie, D.; Baele, G.; Suchard, M.A. Posterior summarisation in Bayesian phylogenetics using Tracer 1.7. Syst. Biol. 2018, 67, 901. [CrossRef]

60. Bouckaert, R.; Heled, J.; Kühnert, D.; Vaughan, T.; Wu, C.-H.; Xie, D.; Suchard, M.A.; Rambaut, A.; Drummond, A.J. BEAST 2: A software platform for Bayesian evolutionary analysis. PLoS Comput. Biol. 2014, 10, e1003537. [CrossRef]

61. Bouckaert, R.; Drummond, A.J. bModelTest: Bayesian phylogenetic site model averaging and model comparison. BMC Evol. Biol. 2017, 17, 42. [CrossRef]

62. Bidegaray-Batista, L.; Arnedo, M.A. Gone with the plate: The opening of the Western Mediterranean basin drove the diversification of ground-dweller spiders. BMC Evol. Biol. 2011, 11, 317. [CrossRef]

63. Peck, S.B. Diversity and distribution of beetles (Insecta: Coleoptera) of the northern Leeward Islands. Insecta Mundi 2011, 678, 159.

64. Garrison, N.L.; Rodriguez, J.; Agnarsson, I.; Coddington, J.A.; Griswold, C.E.; Hamilton, C.A.; Hedin, M.C.; Kocot, K.M.; Ledford, J.M.; Bond, J.E. Spider phylogenomics: Untangling the spider tree of life. PeerJ 2016, 4, e1719. [CrossRef]

65. Bond, J.E.; Garrison, N.L.; Hamilton, C.A.; Godwin, R.L.; Hedin, M.C.; Agnarsson, I. Phylogenomics resolves a spider backbone phylogeny and rejects a prevailing paradigm for orb web evolution. Curr. Biol. 2014, 24, 1765-1771. [CrossRef]

66. Dimitrov, D.; Benavides, L.R.; Arnedo, M.A.; Giribet, G.; Griswold, C.E.; Scharff, N.; Hormiga, G. Rounding up the usual suspects: A standard target-gene approach for resolving the interfamilial phylogenetic relationships of ecribellate orb-weaving spiders with a new family-rank classification (Araneae, Araneoidea). Cladistics 2017, 33, 221-250. [CrossRef] 
67. Matzke, N.J. BioGeoBEARS: BioGeography with Bayesian (and Likelihood) Evolutionary Analysis in R Scripts. R Packag. Version 0.2 2013, 1. Available online: https:/ /CRAN.R-project.org/package=BioGeoBEARS (accessed on 10 September 2021).

68. R Core Team. R: A Language and Environment for Statistical Computing. 2018. Available online: https://www.r-project.org/ (accessed on 15 November 2021).

69. Kimura, M. A simple method for estimating evolutionary rates of base substitutions through comparative studies of nucleotide sequences. J. Mol. Evol. 1980, 16, 111-120. [CrossRef]

70. Čandek, K.; Kuntner, M. DNA barcoding gap: Reliable species identification over morphological and geographical scales. Mol. Ecol. Resour. 2015, 15, 268-277. [CrossRef]

71. Brandley, M.C.; Wang, Y.; Guo, X.; Montes de Oca, A.N.; Fería-Ortíz, M.; Hikida, T.; Ota, H. Accommodating heterogenous rates of evolution in molecular divergence dating methods: An example using intercontinental dispersal of Plestiodon (Eumeces) lizards. Syst. Biol. 2011, 60, 3-15. [CrossRef]

72. Sánchez-Ruiz, A.; Brescovit, A.D.; Alayón, G. Four new caponiids species (Araneae, Caponiidae) from the West Indies and redescription of Nops blandus (Bryant). Zootaxa 2015, 3972, 43-64. [CrossRef]

73. Zhang, J.; Maddison, W.P. New euophryine jumping spiders from the Dominican Republic and Puerto Rico (Araneae: Salticidae: Euophryinae). Zootaxa 2012, 3476, 1-54. [CrossRef]

74. Crews, S.C.; Puente-Rolón, A.R.; Rutstein, E.; Gillespie, R.G. A comparison of populations of island and adjacent mainland species of Caribbean Selenops (Araneae: Selenopidae) spiders. Mol. Phylogenet. Evol. 2010, 54, 970-983. [CrossRef]

75. Dziki, A.; Binford, G.J.; Coddington, J.A.; Agnarsson, I. Spintharus flavidus in the Caribbean-A 30 million year biogeographical history and radiation of a 'widespread species'. PeerJ 2015, 3, e1422. [CrossRef]

76. McHugh, A.; Yablonsky, C.; Binford, G.J.; Agnarsson, I. Molecular phylogenetics of Caribbean Micrathena (Araneae: Araneidae) suggests multiple colonisation events and single island endemism. Invertebr. Syst. 2014, 28, 337-349. [CrossRef]

77. Gillespie, R.G.; Baldwin, B.G.; Waters, J.M.; Fraser, C.I.; Nikula, R.; Roderick, G.K. Long-distance dispersal: A framework for hypothesis testing. Trends Ecol. Evol. 2012, 27, 47-55. [CrossRef] [PubMed]

78. Grant, P.R.; Grant, B.R. Adaptive radiation of Darwin's finches. Am. Sci. 2002, 90, 130. [CrossRef]

79. Lovette, I.J.; Bermingham, E.; Ricklefs, R.E. Clade-specific morphological diversification and adaptive radiation in Hawaiian songbirds. Proc. R. Soc. B Biol. Sci. 2002, 269, 37-42. [CrossRef] [PubMed]

80. Hass, C.A.; Hedges, S.B.; Maxson, L.R. Molecular insights into the relationships and biogeography of West Indian anoline lizards. Biochem. Syst. Ecol. 1993, 21, 97-114. [CrossRef]

81. Glor, R.E.; Gifford, M.E.; Larson, A.; Losos, J.B.; Schettino, L.R.; Lara, A.R.C.; Jackman, T.R. Partial island submergence and speciation in an adaptive radiation: A multilocus analysis of the Cuban green anoles. Proc. R. Soc. B Biol. Sci. 2004, 271, 2257-2265. [CrossRef] [PubMed]

82. Losos, J.B.; Schluter, D. Analysis of an evolutionary species-area relationship. Nature 2000, 408, 847-850. [CrossRef] [PubMed]

83. Hedges, S.B. Biogeography of the West Indies: An overview. In Biogeography of the West Indies: Patterns and Perspectives; Woods, C.A., Sergile, F.E., Eds.; CRC Press: Boca Raton, FL, USA, 2001; pp. 15-33. ISBN 0849320011101.

84. Ř́ičan, O.; Piálek, L.; Zardoya, R.; Doadrio, I.; Zrzavý, J. Biogeography of the Mesoamerican Cichlidae (Teleostei: Heroini): Colonization through the GAARlandia land bridge and early diversification. J. Biogeogr. 2013, 40, 579-593. [CrossRef]

85. Alonso, R.; Crawford, A.J.; Bermingham, E. Molecular phylogeny of an endemic radiation of Cuban toads (Bufonidae: Peltophryne) based on mitochondrial and nuclear genes. J. Biogeogr. 2012, 39, 434-451. [CrossRef]

86. Dávalos, L.M. Phylogeny and biogeography of Caribbean mammals. Biol. J. Linn. Soc. 2004, 81, 373-394. [CrossRef]

87. Binford, G.J.; Callahan, M.S.; Bodner, M.R.; Rynerson, M.R.; Núñez, P.B.; Ellison, C.E.; Duncan, R.P. Phylogenetic relationships of Loxosceles and Sicarius spiders are consistent with Western Gondwanan vicariance. Mol. Phylogenet. Evol. 2008, 49, 538-553. [CrossRef]

88. Matos-Maraví, P.; Núñez Águila, R.; Peña, C.; Miller, J.Y.; Sourakov, A.; Wahlberg, N. Causes of endemic radiation in the Caribbean: Evidence from the historical biogeography and diversification of the butterfly genus Calisto (Nymphalidae: Satyrinae: Satyrini). BMC Evol. Biol. 2014, 14, 199. [CrossRef]

89. Fritsch, P.W. Multiple Geographic Origins of Antillean Styrax. Syst. Bot. 2003, 28, 421-430. [CrossRef]

90. van Ee, B.W.; Berry, P.E.; Riina, R.; Gutiérrez Amaro, J.E. Molecular Phylogenetics and Biogeography of the Caribbean-Centered Croton Subgenus Moacroton (Euphorbiaceae s.s.). Bot. Rev. 2008, 74, 132-165. [CrossRef]

91. Nieto-Blázquez, M.E.; Antonelli, A.; Roncal, J. Historical Biogeography of endemic seed plant genera in the Caribbean: Did GAARlandia play a role? Ecol. Evol. 2017, 7, 10158-10174. [CrossRef]

92. Graham, A. Geohistory models and Cenozoic paleoenvironments of the Caribbean region. Syst. Bot. 2003, 28, 378-386. [CrossRef]

93. MacPhee, R.D.E.; Grimaldi, D.A. Mammal bones in Dominican amber. Nature 1996, 380, 489-490. [CrossRef]

94. Shaw, K.L.; Gillespie, R.G. Comparative phylogeography of oceanic archipelagos: Hotspots for inferences of evolutionary process. Proc. Natl. Acad. Sci. USA 2016, 113, 7986-7993. [CrossRef]

95. Dupin, J.; Matzke, N.J.; Särkinen, T.; Knapp, S.; Olmstead, R.G.; Bohs, L.; Smith, S.D. Bayesian estimation of the global biogeographical history of the Solanaceae. J. Biogeogr. 2017, 44, 887-899. [CrossRef]

96. Magalhaes, I.L.F.; Santos, A.J.; Ramírez, M.J. Incorporating Topological and Age Uncertainty into Event-Based Biogeography of Sand Spiders Supports Paleo-Islands in Galapagos and Ancient Connections among Neotropical Dry Forests. Diversity 2021, 13, 418. [CrossRef] 
97. Gillespie, R.G. Biogeography of spiders on remote oceanic islands of the Pacific: Archipelagoes as stepping stones? J. Biogeogr. 2002, 29, 655-662. [CrossRef]

98. Gillespie, R.G.; Croom, H.B.; Palumbi, S.R. Multiple origins of a spider radiation in Hawaii. Proc. Natl. Acad. Sci. USA 1994, 91, 2290-2294. [CrossRef] [PubMed]

99. Linck, E.; Schaack, S.; Dumbacher, J.P. Genetic differentiation within a widespread "supertramp" taxon: Molecular phylogenetics of the Louisiade White-eye (Zosterops griseotinctus). Mol. Phylogenet. Evol. 2016, 94, 113-121. [CrossRef] [PubMed]

100. Pedersen, M.P.; Irestedt, M.; Joseph, L.; Rahbek, C.; Jønsson, K.A. Phylogeography of a 'great speciator' (Aves: Edolisoma tenuirostre) reveals complex dispersal and diversification dynamics across the Indo-Pacific. J. Biogeogr. 2018, 45, 826-837. [CrossRef]

101. Crews, S.C.; Gillespie, R.G. Molecular systematics of Selenops spiders (Araneae: Selenopidae) from North and Central America: Implications for Caribbean biogeography. Biol. J. Linn. Soc. 2010, 101, 288-322. [CrossRef]

102. Abel, C.; Schneider, J.M.; Kuntner, M.; Harms, D. Phylogeography of the 'cosmopolitan' orb-weaver Argiope trifasciata (Araneae: Araneidae). Biol. J. Linn. Soc. 2020, 131, 61-75. [CrossRef] 